\title{
Readers, Players, and Watchers: EFL Students' Vocabulary Acquisition through Digital Video Games
}

\author{
Mohsen Ebrahimzadeh ${ }^{1}$ \\ ${ }^{1}$ Department of Foreign Languages and Linguistics, Shiraz University, Fars, Iran \\ Correspondence: Mohsen Ebrahimzadeh, Department of Foreign Languages and Linguistics, Shiraz University, \\ Fars, Iran. Tel: 98-917-377-8522. E-mail: m.ebrahimzade94@yahoo.com, s.mebrahimzade@rose.shirazu.ac.ir
}

Received: December 7, 2016 Accepted: January 3, 2017 Online Published: January 5, 2017

doi: 10.5539/elt.v10n2p1 URL: http://dx.doi.org/10.5539/elt.v10n2p1

\begin{abstract}
The present study investigated vocabulary acquisition through a commercial digital video game compared to a traditional pencil-and-paper treatment. Chosen through cluster sampling, 241 male high school students (age 12-18) participated in the study. They were randomly assigned to one of the following groups. The first group, called Readers, involved those who learned vocabulary through intensive reading; the second group, Players, learned vocabulary through playing a digital video game; the third group, Watchers, were trained through watching two classmates play the digital video game. The vocabulary items were first pretested. Next, each group underwent training for five weeks (one session a week). Then, the vocabulary items were posttested. Also, field notes were made. To compare the three groups, a mixed between within subjects ANOVA was run. Results indicated that the Players and Watchers outperformed the Readers. It is concluded that digital video games can be beneficial complementary activities for vocabulary acquisition in high school classrooms.
\end{abstract}

Keywords: digital video games, game-based language learning, vocabulary acquisition, vocabulary learning, reading-based vocabulary learning

\section{Introduction}

\subsection{Language Learning through Digital Video Games (DVGs)}

Game-based learning is defined as 'any initiative that combines or mixes video games and education' (Tsai \& Fan, 2013, p. 115). Considering language learning, Reinhardt and Sykes (2012) proposed a framework which makes a distinction between game-based and game-enhanced language learning. According to them, game-based language learning involves using an educational DVG (i.e., a DVG specifically developed for language learning purposes) while game-enhanced language learning refers to the use of commercial-off-the-shelf DVGs for language learning. According to them, investigating both categories is needed since research on commercial DVGs cannot be replicated with educational DVGs. On the other hand, no educational DVG is all-encompassing and comprehensive. Also, a uniquely game-based consideration might convey a less important role for the teacher or other pedagogical mediations. On the contrary, the multiplicity of resources in a game-mediated environment is what helps it become more effective no matter how rich each one may be.

Multimedia refers to presentation of words (spoken or written) accompanied by images (static or dynamic). Multimedia learning, thus, is 'when people build mental representations from words (such as spoken text or printed text) and pictures (such as illustrations, photos, animation, or video)' (Mayer, 2014, p. 3). Accordingly, multimedia is a form of representation while multimedia learning concerns construction of knowledge from this representation by the learner. Multimedia instruction, therefore, would be the design of multimedia learning environments that promote this knowledge construction. Research shows that learners perform well on retention and transfer tests when words and pictures are presented together-otherwise known as the multimedia principle (Mayer \& Anderson, 1991, 1992).

\subsection{Vocabulary Acquisition}

Words are the base of language which makes them the base of communication indicating the pivotal role of vocabulary knowledge in second language acquisition (Bowen \& Marks, 2002). Accordingly, lacking sufficient word knowledge results in not being able to produce a single utterance. Literature points to different factors that affect second language vocabulary acquisition. For example, Hulstijn (2001) highlighted codability and 
arbitrariness of the form-meaning link as the two most important ones. Codability refers to learning difficulty associated with the form of words. According to him, depending on a learner's current phonotactic knowledge, learning and coding new word forms used in the second language may pose different levels of difficulty. To reiterate, word forms that are morphonologically and phonetically unrelated to a learner's first language may pose great learning difficulty. Laufer's $(1990,1997)$ analyses of what constitutes difficulty in learning second language vocabulary resulted in identification of phonological factors (pronounceability and length), grammatical characteristics (part of speech, inflexional complexity, and derivational complexity), semantic features (abstractness, specificity, and idiomaticity), register restrictions, and multiple meaning. Arbitrariness of the form-meaning link refers to an existing transparent relevance between the form and meaning of an item which can ease its learning.

According to Nation (2001), three general processes lead to successful vocabulary retention for subsequent use including noticing, retrieval, and creative (generative) use. Noticing is a private experience necessary for converting input into intake. Negotiation of meaning, brief explanations, simple definitions, and first language translations help noticing. If a word is retrieved from memory for subsequent use, it is more likely to be remembered later in time. Repetition, for example, is an effective activity in promoting retrieval (Nation, 2001) and understanding events in a DVG (Marsh \& Tainio, 2009). Creative or generative use is utilizing learned vocabulary in different contexts/ways. For example, generative use of vocabulary in a retelling task, vocabulary use in separate directions as a kind of generativity, vocabulary use in discussions in different contexts, and picture generative use of vocabulary have all resulted in better vocabulary learning (Nation, 2001).

Regarding DVGs, consider a gamer who interacts (i.e., repeats, analyzes, and uses) with certain items to achieve a goal at different stages. These interactions provide many repeated encounters in different contexts. Also, the existence of visual cues (e.g., thumbnails, color codes, visual effects) help the learners strengthen what they code into their memory regarding that item. Thus, interactivity in DVGs promotes meaning-making among players (Thorne, Black, \& Sykes, 2009).

\subsection{Focus and Questions of the Study}

'The true secret of why kids spend so much time on their games is that they're learning things they need for their $21^{\text {st }}$ century lives' (Prensky, 2006, p. 4). As such, the field of second language learning too is evaluating the use of DVGs. However, these studies are far from complete (Girard, Ecalle, \& Magnant, 2013; Reinders, 2012). Furthermore, few empirical studies have been conducted that relate gaming experience to second language development (Cornillie, Thorne, \& Desmet, 2012). Moreover, most existing DVG based studies have been done outside the classroom (Thomas, 2012). To fill this gap, we aimed at evaluating vocabulary acquisition through DVGs in high schools. By acquisition, we refer to the weekly evaluation of obtained knowledge (i.e., vocabulary) common in Iranian high schools. Thus, we used weekly posttests to measure acquisition.

The study examined vocabulary acquisition through DVGs in two different approaches to address the lack of equipment in many Iranian high schools. In one, all students played the game (Players) but in the other only two students played and others watched (Watchers). This was done to check the outcomes with limited equipment accessibility. We answered the following questions:

1) How does a commercial DVG affect high school EFL students' vocabulary acquisition?

2) How does playing individually affect vocabulary acquisition as compared to watching others play a commercial DVG?

\section{Background and Previous Studies}

\subsection{DVGs and Learning}

In a comparison between DVGs and other instructional media/instruments, Ang and Zaphiris (2008) explained that a text provides clues as to what the concept, object, or topic in question is and leaves the rest to the reader. A picture, but, conveys this idea by depicting these clues fixed at a particular point in time. For example, a plane can be described through a text while a blue plane would be better comprehended by a picture. Videos can provide information on how the subject changes over time. Still more information could be provided by a toy plane as it can model the behavior of a real plane (e.g., how it flies, what switch does what).

Gee (2003) explained 36 learning principles incorporated in good games for learning such as active-critical learning, semiotic, and committed learning principle. For example, he defined the first principle as 'all aspects of the learning environment (including the ways in which the semiotic domain is designed and presented) are set up to encourage active and critical, not passive, learning' (Gee, 2003, p. 207). For instance, League of Legends (Riot Games, 2009) provides each champion with four special abilities other than their basic attack and passive ability. 
In order to play a champion well, the gamer has to critically evaluate when and in what sequence to use these abilities or which one(s) to max first.

Hitosugi, Schmidt, and Hayashi (2014) examined the effect of a commercial DVG on university students' affect and vocabulary learning. Twenty EFL Japanese students with average-high and intermediate-low proficiency in English participated in this study which included two separate treatments (seventy words introduced in five sessions). Both treatments were almost identical in terms of tasks and activity procedures. The first treatment (seven males, two females, average age: 22.33), included task sheets with embedded new vocabulary. The DVG was used as a supplementary activity. There were no immediate posttests nor teaching of new vocabulary. Upon encountering unknown vocabulary, students were left on their own to look it up or infer the meaning. The second treatment (two males, nine females, average age: 19.10) involved explicit introduction of new vocabulary. Additionally, a vocabulary list was given to the students. Immediate posttests were given and the DVG was included as part of the students' course grade. Data collection involved a vocabulary pretest and an immediate posttest. Also, end-of-unit affect surveys were distributed. The results showed preference and better outcomes for the game-mediated activities and a positive impact on learner affect. They concluded that DVG use facilitates vocabulary learning.

deHaan, Reed, and Kuwada (2010) designed a study to see if interactivity with a music DVG would help or hinder vocabulary recall. The research involved 80 undergraduate, Japanese male and female students (age 18-24) studying computer science. Divided into 40 pairs, the study included two treatments. Each pair included a player and a watcher sitting in separate cubicles. The player interacted with the game and the watcher just observed. The participants were instructed to memorize all the lyrics in five tries (or a maximum of 20 minutes). They could not take notes, pause the game, or use a dictionary. An immediate vocabulary recall cloze test was administered to collect the data. Results indicated that the watchers performed significantly better than the players. The players were reported to have experienced difficulty focusing on both the game and lyric memorization.

\subsection{Vocabulary Learning through Reading}

Reading-based vocabulary learning involves direct (e.g., using glosses, mnemonic devices, lexicography) and indirect (e.g., inferring meaning from context, using background knowledge, making predictions) techniques. These two category of techniques are employed in two different reading comprehension modes called intensive and extensive reading, respectively.

The direct teaching of vocabulary involves a passage with a number of pre- and post-reading activities. Researchers have shown that direct instruction techniques can significantly increase reading comprehension (Peters, Hulstijn, Sercu, \& Lutjeharms, 2009). It was, however, found to be inadequate for fully preparing ESL/EFL learners (Nation \& Waring, 1997). In response to this criticism, Nation and Waring stated that a way for learning 'huge amounts of vocabulary is through indirect or incidental learning' (1997, p. 11) practice such as extensive reading/listening activities. Extensive reading can be defined as reading lots of books with no strict focus on doing exercises (Anderson, 2003). In texts designed for extensive reading, the number of new words should be kept at about two percent to result in optimal learning through the use of guessing from the context strategy - a main concept of extensive reading (Hsueh-Chao \& Nation, 2000).

The effectiveness of extensive reading, however, has been subject to much debate. Some researchers have found indirect techniques to be relatively ineffective compared against intensive (direct) instruction. For example, Min (2008) investigated the effect of two kinds of reading on vocabulary acquisition. One treatment included readings followed by vocabulary activities (definition matching, fill in the blanks, vocabulary translations, sentence writing) with each item appearing three or four times in the activities. The second treatment involved the same vocabulary items presented through selected texts accompanied by thematically related supplemental materials instead of the vocabulary activities. Results showed that the first treatment was more effective and efficient for vocabulary learning.

\section{Method}

Students were aware this was a scientific research project and they could choose to participate or not. However, they were not given any information on what the exact aim of the study was as this would destroy the purpose by making them sensitive to the target vocabulary items. Those who did not participate were given a worksheet based on their course book to practice. The necessary permissions to conduct the study were acquired from authorities in the Ministry of Education. Also, the study was approved by the research ethics committee of Shiraz University. 


\subsection{Participants}

Initially, 241 male, Iranian, junior and senior high school, students (age 12-18) chosen through cluster sampling participated in the study. Twenty five students were removed from final analyses, because they had either (a) played the game at home; (b) cheated on the tests; or (c) missed more than one session.

The study included one junior $(N=61)$ and two senior $(N=153)$ high schools. Through random assignment, the senior high school classes were assigned to one of the three treatments (Readers: $N=75$, Players: $N=65$, Watchers: $N=74$ ). For the junior high school, however, the choice was limited to either the Players' or Watchers' treatment because they did not meet the language background requirement of more than 250 hours of language learning experience set by Cambridge English Language Assessment (2013) syllabus used in the Readers' treatment. The syllabus offers a comprehensive approach to testing English proficiency of learners in high schools and reaches up to level A2 of Common European Framework of Reference. Based on a Headway placement test published by Oxford University Press in 2012, $87.9 \%$ of the participants were classified as level A1.

\subsection{Materials and Instruments}

The study used a mixed method approach. All instruments/materials were piloted four months before this study for observation and revision purposes. Participants of the pilot study were similar in English proficiency, age, and gender to those of the present study.

\subsubsection{Target Vocabulary Items}

Twenty one simple and compound noun phrases (Appendix 1) were extracted from the commercial DVG Warcraft III: The Frozen Throne (Blizzard, 2003). The words were taken from a map known as Defense of the Ancients released by IceFrog (2015). Choice of these words was based on several factors. Firstly, some of them were required for the gameplay so that students could understand what they were doing. Secondly, they had to require a reasonable amount of gold pieces (the DVG's currency) manageable in the available class time. In other words, very expensive items were avoided. Thirdly, it was tried to include vocabulary items with thumbnails more expressive of their meaning. Fourthly, their effects had to be immediately observable so that students could make educated guesses on their Persian equivalent. Thus, being a simple or compound noun was influenced by these criteria.

The order by which these words were presented was dictated by the DVG. These words were not similar in length due to the selection criteria. Each vocabulary item was repeated five times during their respective session since more frequency would require more time considering the design. Furthermore, it was not intended to make the target vocabulary stand out thus raising student sensitivity. They were mainly unknown to the participants since (a) they were not among high-frequency words and (b) they did not exist in students' English textbooks. Pretesting the word list, also, supported this assumption (Table 1).

\subsubsection{Digital Video Game}

The Real-Time Strategy game Warcraft III: The Frozen Throne (Blizzard, 2003) was used. In this genre, gamers position and maneuver units and structures under their control to secure areas of the map and/or destroy their opponents' assets (Rollings \& Adams, 2003; Wolf, 2008). Choice of this commercial DVG was based on the learning opportunities it offered, suitability, GameFlow criteria (Sweetser \& Wyeth, 2005), and technical implementation issues (hardware, software, and training requirements).

Considering the learning opportunities the DVG offered, the vocabulary learning process intended in this study was designed based on noticing, repetition, and generative use (Nation, 2001). Firstly, steps for obtaining certain items were illustrated to the Players/Watchers through a projector (noticing). Secondly, gamers had backpacks or inventories by which they could carry their items around and examine them as many times as they wished or needed (repetition). Thirdly, gamers had the opportunity to combine and manipulate the items stacked in their backpacks in order to produce new items (generative use). These three steps conform to the Presentation Practice Production model by Nunan (1999) as well. Firstly, the items are presented. Then, the students practiced with them. Lastly, the students produced other things with items they owned. Other than these, Gee's (2003) principles were considered.

Through this DVG, students got to use the vocabulary items (player-game interaction). Furthermore, due to its multiplayer nature, the game offered both collaborative and competitive player-player interaction. Thus, there was a constant flow of student-software, student-student, and student-teacher interaction (Morgado, Pereira, \& Quintas-Mendes, 2008). The DVG itself provided feedback which is in line with educational implications of ZPD (Vygotsky, 1978) and GameFlow criteria (Sweetser \& Wyeth, 2005). Also, Sweetser and Wyeth (2005) 
showed that 'Warcraft 3 performed exceptionally in most [GameFlow] criteria' (p. 19).

As for its suitability regarding the audience, according to the Entertainment Software Rating Board and Pan European Game Information, this DVG is suitable for users 12 years old and above. Additionally, ign.com and gamefaqs.com, websites that provide information on DVGs, gave it very high popularity scores ( 9 out of 10 and 88 out of 100 respectively) which suggest its attractiveness.

\subsubsection{Worksheets and Reading Passages}

We developed five reading passages (Appendix 2), each including 600-650 words, to teach the selected list of vocabulary items through the Readers' treatment. These readings were based on the DVG's plot as excerpts tolling the story. Like the Players' and Watchers', Readers had about 50 minutes to go through a worksheet which included one reading and several activities. The worksheets were developed through the following procedures.

Based on the Headway placement test, students' proficiency levels were determined (majority A1). Then, the readings were developed based on the Cambridge English Language Assessment (2013) syllabus level A2 (the Flyers' stage). The reason for using A2 syllabus over A1 was to have the text flow one step above the learners' proficiency conforming to Krashen's (1982) i+1 comprehensible input hypothesis.

The worksheets all started with pre-reading activities including brainstorming and activating prior knowledge. Next came a reading passage followed by post-reading activities including guessing from the context, fill in the blanks, matching, multiple-choice questions, comprehension check, summary writing, and a word puzzle. Adding such activities was based on the finding that students would better learn vocabulary through readings combined with enhancement activities (Min, 2008). Other activities such as repetition and translation were done orally during the reading to encourage student participation and engagement.

The readings were meaning-focused input activities (Nation, 2009) in that they represented a story unfolding session by session. To add an element of language-focused learning (Nation, 2009), the meaning of new words were glossed in the right margin as simplified definitions in English. They were also orally explained in Persian, the students' mother tongue. A number of fill in the blanks and inferential activities were included to promote meaning-focused output (Nation, 2009).

A final remark to be made is that all readings were written based on the reading comprehension criterion stating that above $95 \%$ of a text should be familiar to the reader (Hsueh-Chao \& Nation, 2000; Schmitt, Jiang, \& Grabe, 2011). To achieve this, a word-list was developed based on headwords introduced by the Cambridge English Language Assessment (2013) syllabus (the Flyers' stage). This word-list was programmed to work with Range (Nation, 2002) - a text analyzer software. Through this software, each reading was compared against the Cambridge word-list for the number of new words, types, tokens, and word families. Also, it assessed the number of times each word was repeated. Based on these information, necessary revisions were made to meet the criterion stated above.

\subsubsection{Vocabulary Pretest}

This test included 21 multiple-choice vocabulary items developed by the researchers (Appendix 3). It was administered to all students two weeks before the treatments. Pretest results showed that students were not familiar with the target words as mean scores were far below 21 (Table 1). Students had 14 minutes to finish this test but most were done within 10 minutes.

\subsubsection{Immediate Vocabulary Posttests}

Five immediate vocabulary posttests were developed by the researchers each including 9-12 items (Appendix 4). Administered weekly, they included multiple-choice items on the vocabulary introduced the previous session. Students had to choose a Persian equivalent for each item. These tests included 5-8 questions that did not focus on vocabulary; instead, they asked about the story and videos. This was done to avoid raising student sensitivity toward target vocabulary items. Only the test-items on vocabulary were used in analyses.

\subsubsection{Game Pictures, Cinematics, and Cutscenes}

Each session, a number of relevant images from the DVG were used to highlight the target vocabulary items and steps for creating them (for both Players and Watchers). A video was played for all students at the beginning of each session. It helped visualize a specific part of the story for Readers and raise a sense of purpose and awareness in Players/Watchers. We hardcoded Persian subtitles on the videos to help student comprehension.

\subsubsection{Field Notes}


These researcher notes were focused any special event, behavior, learning and ideas such as likes/dislikes, feelings, environment, or out-of-class experiences. They were made session by session. Since questions of the study were primarily answered based on statistical analyses, these notes were used for data triangulation purposes.

\subsection{Data Collection}

Students first sat the Headway placement test and the vocabulary pretest two weeks before the study. Treatments then began lasting five weeks - one session a week. The sessions ended in less than 50 minutes. During each session, 3-6 vocabulary items were introduced through the following treatments. Totally, 21 words were covered in the study.

As noted earlier, students were aware of the research and their participation. Thus, the learning that occurred through the study was intentional because all students were forewarn about tests (Hulstijn, 2001). The content of these tests, however, were unknown to students since they included items on different materials presented in the previous session so that students would not become sensitive to the vocabulary items. Thus, students had to remember the story, video clip, vocabulary items, and game (depending on their treatment). For analyses, however, only the questions on vocabulary items were used.

Since all treatments involved teamwork, each session, students were divided into several groups except for the Watchers. Group members changed each session to avoid predefined ordering effects. We tried to include five students in each group, a number dictated by the DVG. However, when there were not enough students to form equal groups of five, smaller groups of four were formed. The Watchers were always divided into two groups and one student from each group was randomly selected to play. Chart 1 visualizes the grouping.

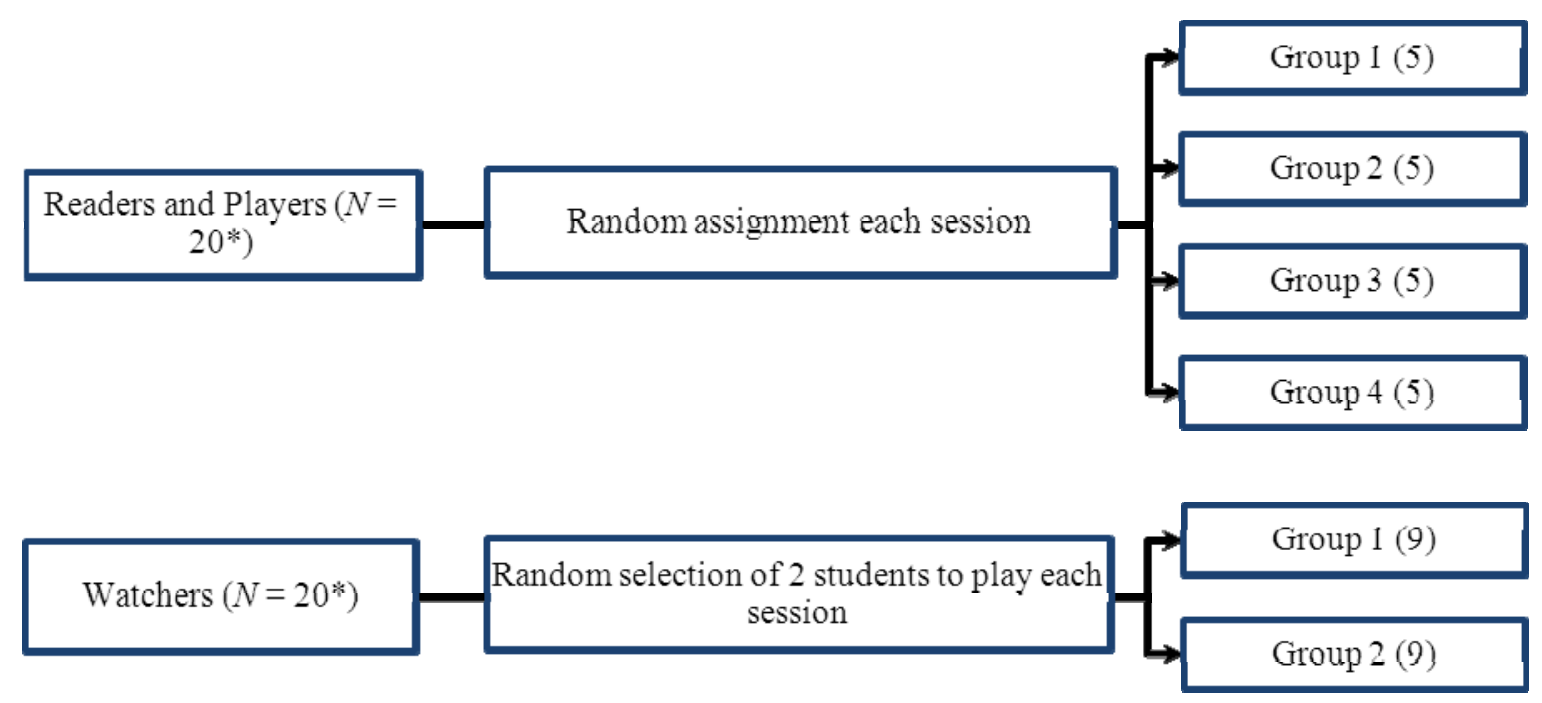

Chart 1. Grouping of students in different treatments

*This total number is just for simplifying the description.

\subsubsection{The Readers' Treatment}

The Readers, first, watched a video from the DVG relevant to part of the story they were going to read about that session. Then, each passage was intensively read and translated into Persian by the researcher. Students were then asked to retell parts of the story using their own words to help structure their knowledge, deepen their cognitive processing, and provide them with an opportunity to produce comprehensible output which is deemed necessary for successful language learning (Swain, 1985; Swain \& Lapkin, 1995). Students were allowed to use English and/or Persian to their convenience since they were not proficient enough to carry out their interactions solely in English. Post-reading activities were worked on immediately after the reading task.

\subsubsection{The Players' and Watchers' Treatment}

Students received training on how to play the game prior to the study. Each session, first, the Players watched a video and information on where the characters were in the story was explained to them to raise a sense of purpose and awareness. A maximum of ten students joined a private server who were then divided into two equal groups. Similar to the Readers' treatment, each session lasted about 50 minutes. Through an overhead projector, 
the vocabulary items and instructions on their location were presented. They, then, played the game trying to attain these items. At this stage, vocabulary was considered as a means to an end - winning the game - not the end itself; nevertheless, students had to pay attention to the items. More specifically, students played, scored, and then went back to their base to purchase and examine the items. In this commercial DVG, thus, gamers learn the vocabulary to play rather than play to learn.

The ultimate goal of the game was to destroy the enemy base. To this end, team members had to improve their avatar's attributes such as strength, agility, damage, armor, intelligence, hitpoints, and mana, all made possible by purchasing the items. Money was earned by killing enemies. Purchase attempts lacking enough money ended up in a prompt notifying them that they needed more gold. Other prompts covered information on units, environment, item combinations, abilities, and resources, all contributing to a constant student-software interaction.

Student-student interaction mainly involved devising plans of action and items to purchase. These interactions were done in students' first language since they were not proficient enough to carry them out in English. However, item names were mentioned in English. Students had to pay attention to their avatar's attributes which were affected by each item they bought. Both during and at the end of each session, teams discussed and decided on a Persian equivalent for each item. The researcher asked leading questions to help them. Visual clues such as pictures, color codes, and in-game definitions were present to guide them. Finally, each player had an inventory (backpack) in which he stacked all his items for future examination/utilization.

The Watchers' treatment followed the same procedure as the Players'. The difference was that in this group the students watched two classmates compete. To add to the competition, bots (computer-controlled avatars) were included. The class was divided into two groups who helped their player by providing hints and encouragement. The game was projected on a screen for everyone to see and follow.

\subsubsection{Immediate Posttests}

Each week an immediate multiple-choice posttest measuring vocabulary acquisition was given to all three groups based on vocabulary items they had studied the last session. Results of these tests were used in statistical data analysis to measure vocabulary acquisition and compare the three groups as follows.

\subsection{Data Analysis}

We used SPSS (v. 21) to analyze the data. As suggested by Stevens (2009), we set the alpha level at .01 to lessen the effects of cooperative learning which violates the ANOVA assumption of having independent observations. To see how the three groups performed on the immediate vocabulary posttests, a mixed between-within subjects ANOVA was run. Field notes were reviewed and analyzed for data triangulation purposes.

\section{Results and Discussions}

\subsection{Examining Homogeneity}

Before going over the results, a one-way between-groups ANOVA was run on the vocabulary pretest scores to see if the three groups (Readers: $N=70, M=6.27, S D=3.98$; Players: $N=64, M=5.44, S D=4.65$; Watchers: $N=71, M=4.61, S D=3.71)$ differed in their knowledge of the target vocabulary items. There was no statistically significant difference $(p=.058)$.

\subsection{Results}

Table 1 shows descriptive statistics of the vocabulary pretest. As suggested by the mean values, the majority of students were not familiar with the target vocabulary items.

Table 1. Descriptive statistics of the vocabulary pretest*

\begin{tabular}{llllll}
\hline & N & Min & Max & Mean & Std. Deviation \\
\hline Readers & 70 & 0 & 15 & 6.27 & 3.98 \\
Players & 64 & 0 & 20 & 5.44 & 4.65 \\
Watchers & 71 & 0 & 13 & 4.61 & 3.71 \\
\hline
\end{tabular}

$*$ Full score $=21$.

Descriptive statistics of the immediate posttests are shown in Table 2. The maximum score on immediate posttests could range from 3-6 based on the number of vocabulary items introduced each session. Compared to 
Readers, Players and Watchers have higher mean scores on all posttests.

Table 2. Descriptive statistics of the immediate posttests

\begin{tabular}{|c|c|c|c|c|c|c|}
\hline & & $\mathrm{N}$ & Min & Max & Mean & Std. Deviation \\
\hline \multirow{3}{*}{$\begin{array}{l}\text { Immediate } \\
\text { posttest } 1 \\
\text { (6 items) }\end{array}$} & Readers & 68 & 0 & 6 & 3.85 & 1.54 \\
\hline & Players & 63 & 0 & 6 & 4.10 & 1.36 \\
\hline & Watchers & 69 & 0 & 6 & 4.30 & 1.33 \\
\hline \multirow{3}{*}{$\begin{array}{l}\text { Immediate } \\
\text { posttest } 2 \\
\text { (4 items) }\end{array}$} & Readers & 72 & 0 & 4 & 2.22 & 1.02 \\
\hline & Players & 62 & 0 & 4 & 2.82 & 1.05 \\
\hline & Watchers & 71 & 0 & 4 & 2.76 & .98 \\
\hline \multirow{3}{*}{$\begin{array}{l}\text { Immediate } \\
\text { posttest } 3 \\
\text { (4 items) }\end{array}$} & Readers & 62 & 0 & 4 & 1.56 & .99 \\
\hline & Players & 57 & 0 & 4 & 2.82 & 1.00 \\
\hline & Watchers & 67 & 1 & 4 & 3.25 & .86 \\
\hline \multirow{3}{*}{$\begin{array}{l}\text { Immediate } \\
\text { posttest } 4 \\
\text { (4 items) }\end{array}$} & Readers & 62 & 0 & 4 & 1.44 & 1.03 \\
\hline & Players & 57 & 0 & 4 & 2.65 & 1.19 \\
\hline & Watchers & 71 & 0 & 4 & 2.39 & 1.08 \\
\hline \multirow{3}{*}{$\begin{array}{l}\text { Immediate } \\
\text { posttest } 5 \\
\text { (3 items) }\end{array}$} & Readers & 62 & 0 & 3 & 1.48 & .90 \\
\hline & Players & 57 & 0 & 3 & 2.39 & .73 \\
\hline & Watchers & 71 & 0 & 3 & 1.94 & .88 \\
\hline
\end{tabular}

To answer the first question, regarding the effect of a commercial DVG on vocabulary acquisition, a mixed between-within subjects ANOVA was run on the five immediate vocabulary posttests which indicated a statistically significant difference $(p=.000)$ with a large effect size (partial eta squared $=.371)$ between the three groups. Next, post-hoc Tukey HSD tests (Table 3) were run to find out which groups differed and to what extent. As shown, Readers performed significantly lower than both Players and Watchers $(p=.000)$. There was no significant difference between Players and Watchers $(p=.470)$ which answers the second question that asked if there were any differences between the Players and Watchers in terms of vocabulary acquisition.

Table 3. Difference between the three groups for vocabulary acquisition

\begin{tabular}{lllll}
\hline (I) Group & (J) Group & Mean & Std. error & Sig. \\
name & name & difference (I-J) & & \\
\hline Readers & Players & $-1.0297^{*}$ & .11739 & .000 \\
& Watchers & $-.8944^{*}$ & .11155 & .000 \\
\hline Players & Readers & $1.0297^{*}$ & .11739 & .000 \\
& Watchers & .1352 & .11506 & .470 \\
\hline Watchers & Readers & $.8944^{*}$ & .11155 & .000 \\
& Players & -.1352 & .11506 & .470 \\
\hline
\end{tabular}

Based on observed means.

The error term is Mean Square (Error) $=.357$.

*. The mean difference is significant at the .01 level.

\subsection{Discussions}

The first question asked how DVGs affect high school EFL students' vocabulary acquisition. The findings seem 
to indicate that DVG-learners significantly outperformed the Readers ( $p=.000$, Cohen's $d=.371$ ). This finding agrees with previous studies by deHaan (2005) and Hitosugi, Schmidt, and Hayashi (2014) who also found higher achievement through DVGs.

The difference between DVG-learners and the Readers may be attributed to design, game-play, and multimedia learning. Regarding the design and game-play, this DVG offers a simple map with one main goal-destroying the enemy base. To achieve this, gamers need to gain experience to level up by killing enemies. This improves their avatars' attributes including damage, agility, strength, intelligence, armor, hit points, and mana. The process also provides gamers with some gold pieces which can be used to buy items that affect these attributes. It means that gamers need to know exactly what each of these attributes mean and how each item affects them. This highlights the need for English.

Each unsatisfying outcome was quickly noticed through the immediate feedback. The unsatisfactory outcomes caused replays (reappraisals) with closer attention and more thoughtful action resulting from reflection (Buckley \& Anderson, 2006). This involved the gamer in an active process of critically examining all relevant issues to the immediate situation (Gee, 2003). For instance, the choice to use which ability at what time to achieve the desired outcome was influenced by understanding what that ability did (the role of language). This cycle resulted in the acquisition of new vocabulary items involved in the process. Moreover, students' claim to have successfully used the skill in other similar situations to guess the meaning of unfamiliar vocabulary could also be attributed to learning since similar situations activate scripts - concepts learned and rehearsed through an understanding of goals, causation, and plans of action (Abelson, 1981; Schank \& Abelson, 1977). For example, 'I use this in Clash of Clans [a famous massively multiplayer online DVG] too sir' said one student.

Additionally, in keeping with Nunan's (1999) Presentation Practice Production model, the DVG presented each vocabulary item through textual (names and descriptions) and visual (color codes and pictures) means, allowing students to examine it using their backpacks. This is also in keeping with Gee's (2003) explicit information on-demand and just-in-time principle. Next, the students practiced using the item, seeing how it affected their skills in battle. Lastly, they used the items to produce better, stronger items or display certain feats. 'We see the words, we use them like we can touch them, and we learn them sir' said one student. Agreeing with previous research such as Allum (2004) and Nation (2001), the productive practice may have particularly improved vocabulary acquisition since it needs complete attention to object names and prerequisites. This notion, however, is in need of further investigation.

The findings on the facilitative role of multimedia in learning agree with previous research (e.g., Clark \& Mayer, 2011, ch. 4; Mayer \& Anderson, 1992; Mayer \& Gallini, 1990) in that interactivity and multimedia presentation enhance learning. Game-learners identified the DVG as an effective facilitator of vocabulary acquisition since it allowed for close examination and utilization of the vocabulary items. However, they noted that game-mediated language learning should not replace their course books and that there should be books and notes to study and review at home. This point was repeatedly mentioned by students since they were not allowed to take notes. For example, they said 'we need to have something to study at home to feel prepared for the test next session.' Note taking was forbidden in order to confine the effects of treatments to the classroom. This way, out of class factors such as reviewing at home could be controlled better.

As noted in Gee's (2003) multimodal principle regarding the construction of meaning through various modalities such as images, texts, and interactions, eased comprehension of the meanings through the multimedia principle seems to have played an important role in vocabulary acquisition as investigated in the present study. Clark and Mayer highlighted the need for multimedia presentation to help learner comprehension since it 'can encourage learners to engage in active learning by mentally representing the material in words and in pictures and by mentally making connections between the pictorial and verbal representations' (2011, pp. 71; see also Mayer, 2014). In sum, multimedia seems to have helped students fix the vocabulary in their minds promoting learning which is in line with previous research by Feldmesser (2009).

Color codes used in the DVG were also useful in making educated guesses on the meanings. For example, there were two bars on the DVG's user interface: a health bar (green) and a mana bar (blue). Recognizing that green represents health and blue is for mana, some students could guess that a green potion would probably restore their life force. Thus, they made connections between color details and guessed the meaning. Understanding these relationships corresponds to Gee's (2003) semiotic principle which states that an appreciation of multiple sign systems such as images, artifacts, words, and actions is essential for learning through DVGs.

Specifically on account of the second question, there was no statistically significant difference between Players and Watchers. This could be attributed to two main reasons. Firstly, both treatments had discussions on choosing 
a Persian equivalent in quite a similar quality and used the same instruments. Secondly, while Players had more hands-on-task experience, Watchers experienced a more comfortable and relaxed atmosphere, allowing them better focus. This finding appear to contradict that of deHaan et al. (2010) who found the Watchers to show better performance. The contradiction seems to stem from timing and instruments. As for time, deHaan et al. (2010) allotted 20 minutes requiring fast action but we allowed about 50 minutes affording time for more practice and reflection. Regarding instruments, while vocabulary items were part of the secondary objectives in the DVG we used, deHaan et al. (2010) used a DVG in which, as they put it themselves, 'English was not crucial for gameplay' (p. 85). In other words, although deHaan et al. (2010) instructed the Players to memorize the lyrics, it did not occupy a significant role in succeeding in game-play.

\section{Conclusion}

The study examined vocabulary acquisition through a commercial DVG. Participants were assigned to one of the following three groups: Readers, Players, and Watchers. We found Players and Watchers to outperform Readers. According to our findings, DVGs seem to offer potential for inclusion in educational settings. Agreeing with Reinhardt and Sykes (2012), DVGs should not be considered a replacement for course books but more of complementary or supplemental activities that could be scaffolded into existing curricula (see also Neville, Shelton, \& McInnis, 2009). Comparing the findings with similar studies, it seems that DVG features including genre, story, user interface, and design, play an important role in its effectiveness for vocabulary acquisition. Since the results showed no difference between Players and Watchers, both treatments seem viable in promoting vocabulary acquisition.

Memorizing vocabulary through a dictionary look up takes less than a minute. Discovering the meaning in a commercial DVG, however, may require 10 times more time. Yet, this is counterbalanced by better acquisition through game-mediated language learning. In line with Gee (2003) and Van Eck (2009), thus, we suggest that DVGs be included in high school classrooms.

The choice of which commercial DVG to use for vocabulary learning should be made with great care however. Firstly, the DVG should help gamers understand the target vocabulary through different means such as thumbnails, explanations, color codes, and utilization. Secondly, the DVG should offer means through which gamers could have easy access to the target vocabulary (e.g., backpacks, inventories). Thirdly, there should be adequate feedback on how to obtain the items to avoid confusion. Lastly, the target vocabulary should have an important, tangible, visible role in the game-play.

This study was limited in several ways. Firstly, the students were not equal in terms of computer knowledge although most were similar in terms of language proficiency. Secondly, a certain ANOVA assumption could not be met which limits generalization of the findings. Thirdly, the immediate vocabulary posttests included 3-6 target items which is a small number for measuring differences between groups. However, no more items could be included due to the design of the study. Fourthly, the students had out-of-class interactions on their classroom experience which might have affected the outcomes.

\section{References}

Abelson, R. P. (1981). Psychological status of the script concept. American Psychologist, 36(7), 715-729. https://doi.org/10.1037/0003-066X.36.7.715

Allum, P. (2004). Evaluation of CALL: Initial vocabulary learning. ReCALL, 16(2), 488-501. https://doi.org/10.1017/S0958344004001624

Anderson, N. (2003). Reading. In D. Nunan (Ed.), Practical English language teaching (pp. 67-86). New York, NY: McGraw-Hill.

Ang, S. C., \& Zaphiris, P. (2008). Computer games and language learning. In T. T. Kidd, \& H. Song (Eds.), Handbook of research on instructional systems and technology (Vol. 1, pp. 449-462). Hershey, PA: IGI Global. https://doi.org/10.4018/978-1-59904-865-9.ch032

Blizzard. (2003). Warcraft III: The Frozen Throne [Computer software]. USA: Blizzard Entertainment. Retrieved from http://eu.blizzard.com/en-gb/games/war3/

Bowen, T., \& Marks, J. (2002). Inside teaching: Options for English language teachers. Oxford: Macmillan Heinemann.

Buckley, K. E., \& Anderson, C. A. (2006). A theoretical model of the effects and consequences of playing video games. In P. Vorderer, \& J. Bryant (Eds.), Playing video games: Motives, responses, and consequences (pp. 363-378). Mahwah, NJ: Lawrence Erlbaum. 
Cambridge English Language Assessment. (2013). Cambridge Young Learners English (YLE). Cambridge: Association of Language Testers in Europe.

Clark, R. C., \& Mayer, R. E. (2011). E-Learning and the science of instruction proven guidelines for consumers and designers of multimedia learning ( $3 \mathrm{rd}$ ed.). San Francisco, CA: Pfeiffer. https://doi.org/10.1002/9781118255971

Cornillie, F., Thorne, S. L., \& Desmet, P. (2012). Digital games for language learning: From hype to insight? [Special issue]. ReCALL, 24(3), 243-256. https://doi.org/10.1017/S0958344012000134

deHaan, J. W. (2005). Acquisition of Japanese as a foreign language through a baseball video game. Foreign Language Annals, 38(2), 278-282. https://doi.org/10.1111/j.1944-9720.2005.tb02492.x

deHaan, J. W., Reed, W. M., \& Kuwada, K. (2010). The effect of interactivity with a music video game on second language vocabulary recall. Language Learning \& Technology, 14(2), 74-94.

Feldmesser, K. (2009). A video game, a Chinese Otaku, and her deep learning of a language. In R. E. Ferdig (Ed.), Handbook of research on effective electronic gaming in education (pp. 422-450). Hershey, PA: Information Science Reference. https://doi.org/10.4018/978-1-59904-808-6.ch025

Gee, J. P. (2003). What video games have to teach us about learning and literacy. New York, NY: Palgrave Macmillan.

Girard, C., Ecalle, J., \& Magnant, A. (2013). Serious games as new educational tools: How effective are they? A meta-analysis of recent studies. Journal of Computer Assissted Learning, 29(3), 207-219. https://doi.org/10.1111/j.1365-2729.2012.00489.x

Hitosugi, C. I., Schmidt, M., \& Hayashi, K. (2014). Digital game-based learning (DGBL) in the L2 classroom: The impact of the UN's off-the-shelf videogame, Food Force, on learner affect and vocabulary retention. CALICO Journal, 31(1), 19-39. https://doi.org/10.11139/cj.31.1.19-39

Hsueh-Chao, M. H., \& Nation, I. S. P. (2000). Unknown vocabulary density and reading comprehension. Reading in a Foreign Language, 13(1), 403-430.

Hulstijn, J. H. (2001). Intentional and incidental second-language vocabulary learning: A reappraisal of elaboration, rehearsal and automaticity. In P. Robinson (Ed.), Cognition and second language instruction (pp. 258-286). Cambridge: Cambridge University Press. https://doi.org/10.1017/CBO9781139524780.011

IceFrog. (2015). Defense of the Ancients (V. 6.78c AI 1.4e) [Computer software]. Retrieved from http://www.playdota.com/

Krashen, S. D. (1982). Principles and practice in second language acquisition. Oxford: Pergamon Press.

Laufer, B. (1990). Why are some words more difficult than others? - Some intralexical factors that affect the learning of words. International Review of Applied Linguistics in Language Teaching, 28(4), 293-308. https://doi.org/10.1515/iral.1990.28.4.293

Laufer, B. (1997). What's in a word that makes it hard or easy: Some intralexical factors that affect the leaming of words. In N. Schmitt, \& M. McCarthy (Eds.), Vocabulary: Descripfion, acquisition and pedagogy (pp. 140-155). Cambridge, UK: Cambridge University Press.

Marsh, A. P., \& Tainio, L. (2009). Other-repetition as a resource for participation in the activity of playing a video game. The Modern Language Journal, 93(2), 153-169. https://doi.org/10.1111/j.1540-4781.2009.00853.x

Mayer, R. E. (2014). Introduction to multimedia learning. In R. E. Mayer (Ed.), The Cambridge handbook of multimedia learning (2nd ed.). New York, NY: Cambridge University Press. https://doi.org/10.1017/CBO9781139547369.005

Mayer, R. E., \& Anderson, R. B. (1991). Animations need narrations: An experimental test of a dual-coding $\begin{array}{llll}\text { hypothesis. Journal of Educational Psychology, } & \text { 83(4), }\end{array}$ https://doi.org/10.1037/0022-0663.83.4.484

Mayer, R. E., \& Anderson, R. B. (1992). The instructive animation: Helping students build connections between words and pictures in multimedia learning. Journal of Educational Psychology, 84(4), 444-452. https://doi.org/10.1037/0022-0663.84.4.444

Mayer, R. E., \& Gallini, J. K. (1990). When is an illustration worth ten thousand words? Journal of Educational Psychology, 82(4), 715-726. https://doi.org/10.1037/0022-0663.82.4.715 
Min, H.-T. (2008). EFL vocabulary acquisition and retention: Reading plus vocabulary enhancement activities and narrow reading. Language Learning, 58(1), 73-115. https://doi.org/10.1111/j.1467-9922.2007.00435.x

Morgado, L., Pereira, A., \& Quintas-Mendes, A. (2008). The 'Contract' as a pedagogical tool in e-Learning. In A. J. Mendes, I. Pereira, \& R. Costa (Eds.), Computers and education: Towards educational change and innovation (pp. 63-72). London: Springer London. https://doi.org/10.1007/978-1-84628-929-3_7

Nation, I. S. P. (2001). Learning vocabulary in another language. Cambridge: Cambridge University Press. https://doi.org/10.1017/CBO9781139524759

Nation, I. S. P. (2002). Range (V. 1.29) [Computer software]. Retrieved from http://www.victoria.ac.nz/lals/about/staff/paul-nation

Nation, I. S. P. (2009). Teaching ESL/EFL reading and writing. New York, NY: Routledge.

Nation, I. S. P., \& Waring, R. (1997). Vocabulary size, text coverage, and word lists. In N. Schmitt \& M. McCarthy (Eds.), Vocabulary: Description, acquisition, and pedagogy (pp. 6-19). Cambridge: Cambridge University Press.

Neville, D. O., Shelton, B. E., \& McInnis, B. (2009). Cybertext redux: Using digital gamebased learning to teach L2 vocabulary, reading, and culture. Computer Assisted Language Learning, 22(5), 409-424. https://doi.org/10.1080/09588220903345168

Nunan, D. (1999). Second language teaching \& learning. Florence, KY: Heinle \& Heinle.

Peters, E., Hulstijn, J. H., Sercu, L., \& Lutjeharms, M. (2009). Learning L2 German vocabulary through reading: The effect of three enhancement techniques compared. Language Learning, 59(1), 113-151. https://doi.org/10.1111/j.1467-9922.2009.00502.x

Prensky, M. (2006). Don't bother me mom--I'm learning! How computer and video games are preparing your kids for 21st century success - and how you can help! St. Paul, MN: Paragon House.

Reinders, H. (Ed.). (2012). Digital games in language learning and teaching. Basingstoke, UK: Palgrave Macmillan. https://doi.org/10.1057/9781137005267

Reinhardt, J., \& Sykes, J. M. (2012). Conceptualizing digital game-mediated L2 learning and pedagogy: Game-enhanced and game-based research and practice. In H. Reinders (Ed.), Digital games in language learning and teaching (pp. 32-49). New York, NY: Palgrave Macmillan. https://doi.org/10.1057/9781137005267.0008

Riot Games. (2009). League of Legends [Computer software]. Los Angeles, Ca: Riot Games.

Rollings, A., \& Adams, E. (2003). Andrew Rollings and Ernest Adams on game design. San Francisco, CA: New Riders Publishing.

Schank, R. C., \& Abelson, R. P. (1977). Scripts,plans, goals and understanding: An inquiry into human knowledge structures. Hillsdale, NJ: Lawrence Erlbaum.

Schmitt, N., Jiang, X., \& Grabe, W. (2011). The percentage of words known in a text and reading

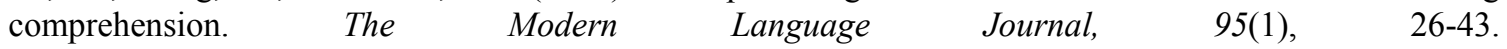
https://doi.org/10.1111/j.1540-4781.2011.01146.x

Stevens, J. P. (2009). Applied multivariate statistics for the social sciences (5th ed.). New York, NY: Routledge.

Swain, M. (1985). Communicative competence: Some roles of comprehensible input and comprehensible output in its development. In S. Gass \& C. Madden (Eds.), Input and second language acquisition Rowley, MA: Newbury House.

Swain, M., \& Lapkin, S. (1995). Problems in output and the cognitive processes they generate: A step towards second language learning. Applied Linguistics, 16(3), 371-391. https://doi.org/10.1093/applin/16.3.371

Sweetser, P., \& Wyeth, P. (2005). GameFlow: A model for evaluating player enjoyment in games. ACM Computers in Entertainment, 3(3), 1-24. https://doi.org/10.1145/1077246.1077253

Thomas, M. (2012). Contextualizing digital game-based language learning: Transformational paradigm shift or business as usual? In H. Reinders (Ed.), Digital games in language learning and teaching (pp. 11-31). Basingstoke, UK: Palgrave Macmillan. https://doi.org/10.1057/9781137005267.0007 
Thorne, S. L., Black, R. W., \& Sykes, J. M. (2009). Second language use, socialization, and learning in internet interest communities and online gaming. The Modern Language Journal, 93, 802-821. https://doi.org/10.1111/j.1540-4781.2009.00974.x

Tsai, C. W., \& Fan, Y. T. (2013). Research trends in game-based learning research in online learning environments: A review of studies published in SSCI-indexed journals from 2003 to 2012. British Journal of Educational Technology, 44(5), 115-119. https://doi.org/10.1111/bjet.12017

Van Eck, R. (2009). A guide to integrating COTS games into your classroom. In R. E. Ferdig (Ed.), Handbook of research on effective electronic gaming in education (pp. 179-199). Hershey, PA: IGI Global. https://doi.org/10.4018/978-1-59904-808-6.ch011

Vygotsky, L. S. (1978). Mind in society: The development of higher psychological processes. Cambridge, MA: Harvard University Press.

Wolf, M. J. P. (2008). The video game explosion: A history from PONG to Playstation and beyond. Westport, CT: Greenwood Press.

\section{Appendices}

\section{Appendix 1: Target Vocabulary Items}

\begin{tabular}{|c|c|c|c|}
\hline \multirow{2}{*}{ No } & \multicolumn{2}{|c|}{ Item } & \multirow{2}{*}{ Session } \\
\hline & English & Persian & \\
\hline 1 & Damage & آسـيـب & 1 \\
\hline 2 & Armor & زر & 1 \\
\hline 3 & Agility & جـا بـكـى & 1 \\
\hline 4 & Healing salve & مــر هم شفــا د هــــــــ & 1 \\
\hline 5 & Ally & مـتحـد & 1 \\
\hline 6 & Gauntlets of strength & 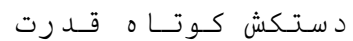 & 1 \\
\hline 7 & Ironwood branch & شـاخـــ آ هـنـــن & 2 \\
\hline 8 & Status & و ضعـــت & 2 \\
\hline 9 & Intelligence & هـ ش ش & 2 \\
\hline 10 & Mana & جـا د و & 2 \\
\hline 11 & Buckler & ســـر كـو جكك & 3 \\
\hline 12 & Robe of the magi & رد اى زرتـشتى & 3 \\
\hline 13 & Chainmail & زره زبنـيـرى & 3 \\
\hline 14 & Boots of speed & يــوتــــن سـرعت & 3 \\
\hline 15 & Gloves of haste & 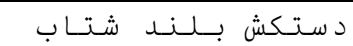 & 4 \\
\hline 16 & Broadsword & شمشيـر زيهن & 4 \\
\hline 17 & Quarterstaff & عصـاى جـنـــى & 4 \\
\hline 18 & Claymore & شمشيـر دو دم & 4 \\
\hline 19 & Perseverance & اسـتــــامـت & 5 \\
\hline 20 & Power treads & كَــام هـاى يــرتــــــان ان & 5 \\
\hline 21 & Recipe & دستــور ر الـعـمل & 5 \\
\hline
\end{tabular}




\section{Appendix 2: A Sample Page of the Worksheets (Session 4)}

\section{Season 2}

Lesson 2

\section{The Frozen Throne}

\author{
Alliance Campaign: To the North
}

\section{Pre-reading Activities:}

Retelling

Try and remember what happened in the story last session. Present it to the class.

Predicting and Skimming

Look at the title, the pictures, and the phrases below. What do you think happens in the story today? lord Illidan you shall be my right hand to kill Magtheridon there are two gates travel with me to the north to kill Lich King many different soldiers to the icy north together

Now, skim the passage and check your predictions.

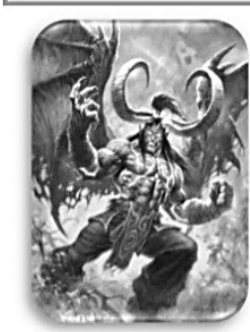

Prince Kael and the Naga finally found Illidan. The first thing Prince Kael asked Illidan was 'can you help us solve our magic problem?' 'There is no solution my young Prince; but I can give you a new source' answered lllidan. Prince Kael thought for a moment and then said: so be it; from now on, you can think of us as your allies lord Illidan! 'And you shall be my right hand,' Illidan went on 'our first task is to kill Magtheridon; he's the lord of this land and we need to take it from him.'

It took them a few days to make their camp. After that, Illidan sent a few scouts to Magtheridon's city. When they came back, they reported that a group of undead protect a very strange item; 'it's called the gloves of haste' they said. 'We should surely look into that; Kael, that is your first task; bring me the gloves and I shall tell you about your problem' said Illidan. 'Consider it done my lord.' said Kael. The Prince and

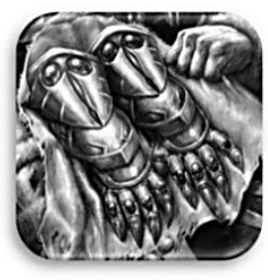
his men left the camp and found the gloves. Prince Kael quickly returned and gave them to Illidan. He wore them and was surprised; the gloves made him much quicker!

The next morning, Illidan explained to Kael that he met a great demon lord named Jaeden; he said: Jaeden promised me strength; and in return, he asked me to kill the Lich King in the north; and he also promised me power beyond imagination; now, to kill the Lich King, I need an army; if you travel with me to the north and help me do it, I promise that I'll solve your magic problem. Prince Kael stepped forward and said: I know the legend of the ice crown and the frozen throne; my claymore is yours to command; we'll go to the icy north together.

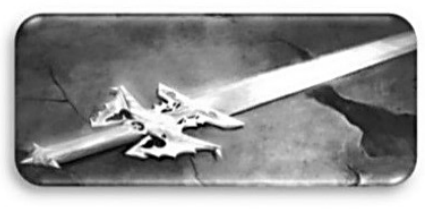

Solve: to find the answer to a problem.

Source: a place, person or a thing that you sth from.

Task: a work that you must do.

Scout: a person sent ahead to find information about the enemy.

Gloves of haste: a covering for the hand that makes you act faster.

Demon: very evil.

Imagination: ability to think of new ideas.

Crown: a circle made of gold that kings wear on their head.

Claymore: a large sword with two sharp sides. 


\section{Appendix 3: Vocabulary Pretest}

Pre-test (Screening Test)

$$
\text { كلاس: }
$$

\section{به نام خعا}

$$
\text { مدرسه: }
$$

نام و نام خانوادَّي:

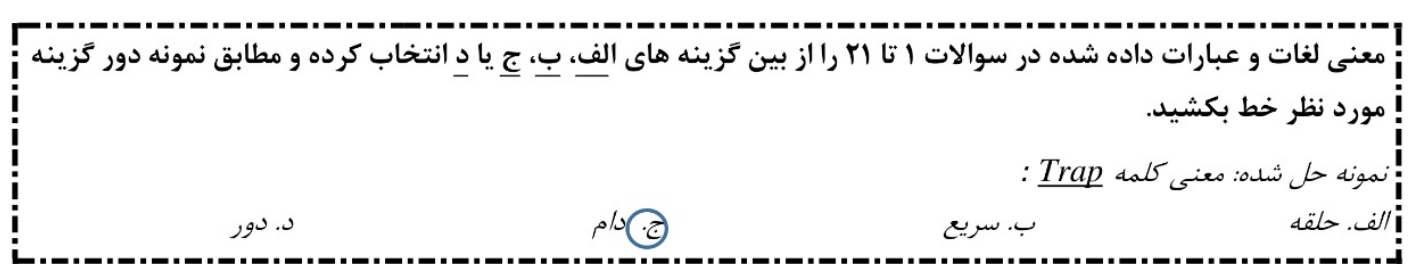

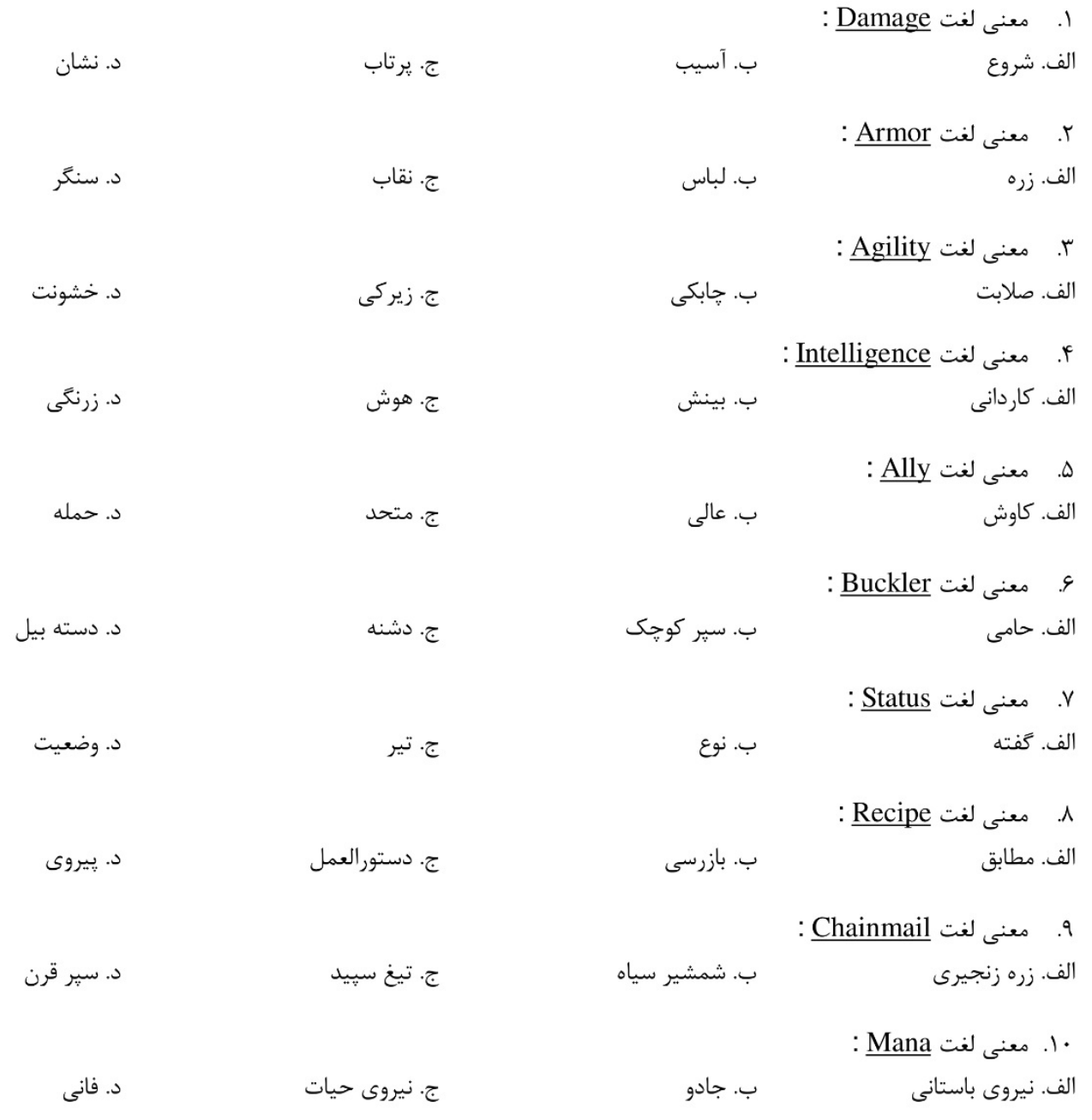




\begin{tabular}{|c|c|c|}
\hline & & 11. معنى لغت Broadsword : \\
\hline 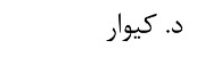 & 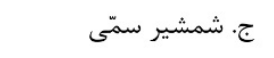 & 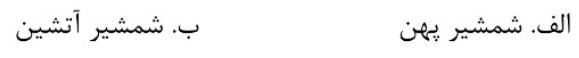 \\
\hline & & ז ו. معنى لغت Quarterstaff \\
\hline 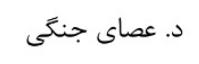 & 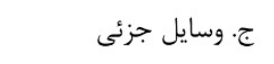 & 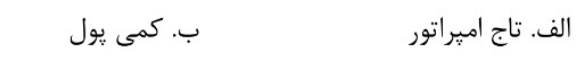 \\
\hline & & rا. معنى لغت Claymore \\
\hline 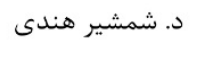 & 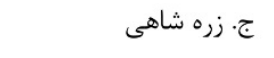 & 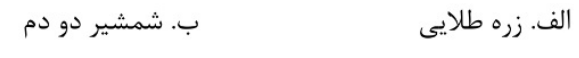 \\
\hline & & |f ا. معنى لغت Perseverance \\
\hline 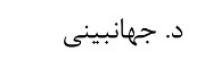 & 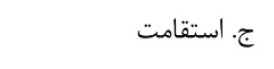 & 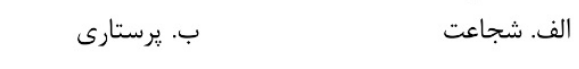 \\
\hline & & ها. ـنى لغت Ironwood Branch \\
\hline 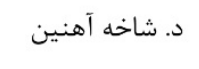 & 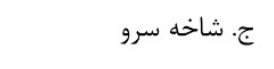 & 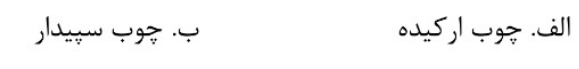 \\
\hline & & 19. معنى لغت Robe of the Magi. \\
\hline 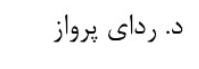 & 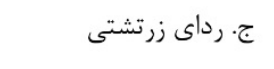 & الف. رداى حفاظت \\
\hline & & : Gauntlets of Strength IV Sعنى لغت \\
\hline 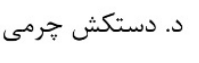 & 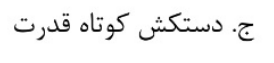 & الف. زره كوتاه خرمى \\
\hline & & 11. معنى لغت Boots of Speed: \\
\hline 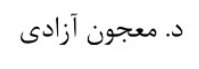 & 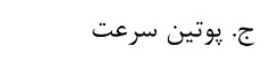 & 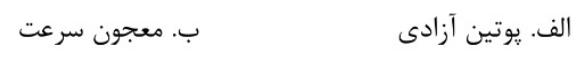 \\
\hline & & 19. معنى لغت Healing Salve \\
\hline 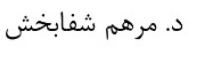 & 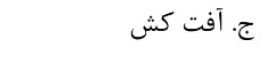 & الف. معجون رهايى \\
\hline & & . r. معنى لغت Power Treads \\
\hline د. تحمه رهايى & ج ج קمه نبرد & الف. كامهاى يرتوان \\
\hline & & ا ا. معنى لغت Gloves of Haste \\
\hline 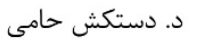 & 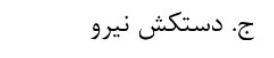 & الف. دستكش نيرنَ \\
\hline
\end{tabular}




\section{Appendix 4: The Fourth Session's Immediate Posttest (Only the Highlighted Questions Were Used in}

\section{Analyses)}

Appendix 4.1: Readers' Test

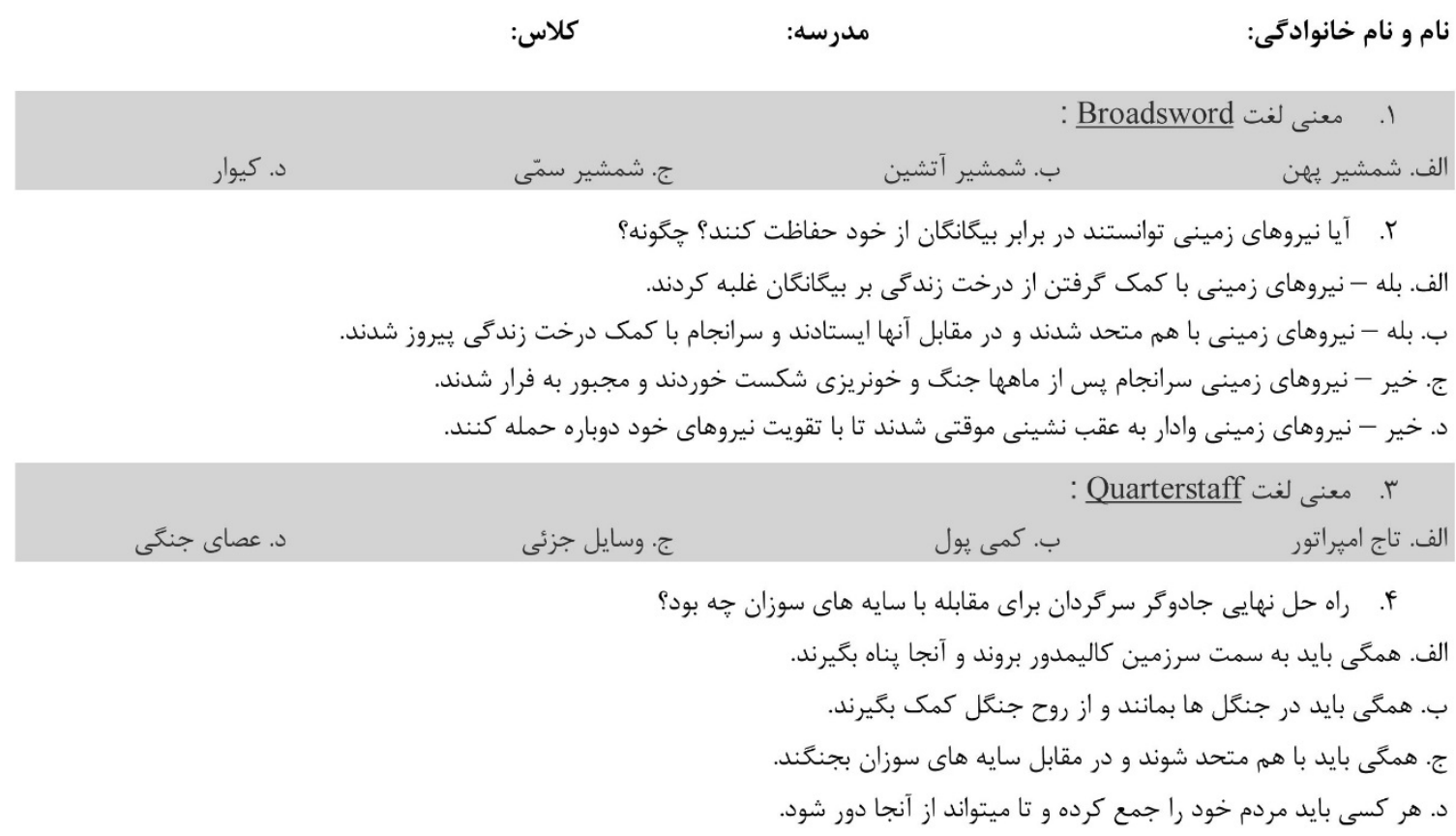

5. Why Illidan wanted to kill the Lich King?

a) Because Jaeden commanded him to do so.

b) Because he hated him since a long time ago.

c) Because Illidan wanted to live in the north.

d) Because the Lich King wanted to attack them.

6. Why Jaeden was angry with Illidan?

a) Because Magtheridon told him to do so.

b) Because Magtheridon was a better servant for Jaeden.

c) Because Illidan killed Magtheridon who served Jaeden.

d) Because he thought Illidan could not kill the Lich King.

\begin{tabular}{|c|c|c|c|}
\hline & & & V. معنى لغت \\
\hline د. شمشير هندى & ج· زره شاهى & ب. شمشير دو دم & الف. زره طلايى \\
\hline
\end{tabular}

8. What did Jaeden and Illidan discuss?
a) killing Lich king
b) need for food
c) Magtheridon's end
d) Prince Kael's problem

9




\section{Appendix 4.2: Players' and Watchers' Test}

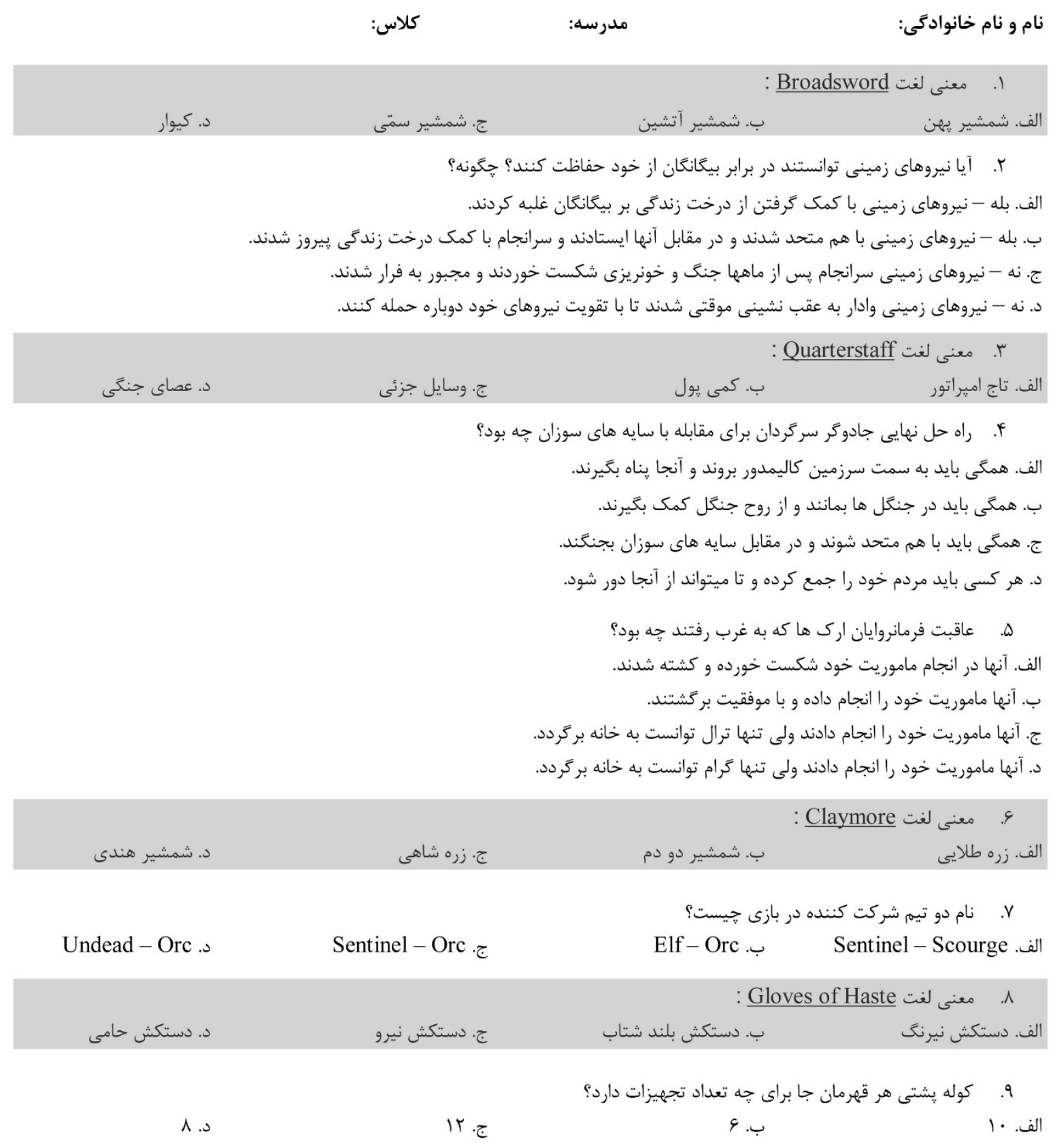

\section{Copyrights}

Copyright for this article is retained by the author(s), with first publication rights granted to the journal.

This is an open-access article distributed under the terms and conditions of the Creative Commons Attribution license (http://creativecommons.org/licenses/by/4.0/). 